\title{
Growth of City Regions and Bank Branch Localization
}

\author{
Oliver Rafaj ${ }^{1}$, Maria Siranova ${ }^{1, *}$ \\ ${ }^{1}$ University of Economics in Bratislava, Dolnozemska cesta 1, 85235 Bratislava, Slovakia
}

\begin{abstract}
Current research in regional science focuses on the relationships between production factors and their impact on the overall product of cities, as well as topics dealing with the contribution of different city sizes to the economic growth. However, the ongoing process of international financialization tightly linked to access to finance gains on importance as the financial sector serves as a conduit for capital transformation in space. This article examines the economic growth of Slovak city regions and estimates the effect of access to finance measured by bank branches availability in these regions, once controlling for the standard impact of production factors. We construct non-overlapping three 5 -years periods panel for more than 60 Slovak urban regions and combine it with data on bank branches localization on the county level and for major domestic commercial banks. The standard Cobb-Douglas production function is utilized with regional output calculated for firms with more than 20 employees and measures of physical and quantity and quality of human capital as conditioning variables. The characteristics of individual banks with bank branches located inside the city regions are included in order to investigate quality effect of financialization process. In order to control for time-invariant region-specific effect we use fixed effect panel model. Potential endogeneity issue between regional productivity and bank branch localization is addressed by the use of IV-2SLS estimator.
\end{abstract}

\section{Introduction}

Role of access to finance has been widely studied predominantly in the macro-finance literature. Traditionally, access to finance has been approximated by number of bank branches per capita or number of ATMs available per unit of population. Most of the studies thus examine effect of contraction (expansion) on macro (country) level or individual bank level, but less on regional level. This standard approach, while having many advantages, also prohibits asking of many relevant questions, such as how does the bank in host country responds to the call from its mother bank or whether regional determinants matter when credit rationing is present.

It is definitely true, that ongoing financialization of world economy might render question of local bank branch effects obsolete. Alternative financial services providers from the FINTEC industry needs to be acknowledged and taken into account. Potential new

*Corresponding author: maria.siranova@euba.sk 
measures of financial access, such as extent of smart mobile phone banking via mobile banking accounts need to be accounted for. However, the issue of bank branches localization and its effect of local production should still remain strongly rooted in economic research, due to both conceptual reasons (banks still serve as the major financial intermediator) as well as data (in-)availability. This has been recently illustrated by two newest studies who show that bank branch closing is estimated to have an adverse effect on SME lending [1] as well as on households financial situation [2].

On top of that, with the newest advances in network and spatial modelling the question of optimal bank network structure, possible contagion effects and role of centralization vs. decentralization should once again spur attention of researchers in order to investigate their effects in presence of spatial dynamics in local economy.

According to our knowledge, this study represents a first attempt in this direction in conditions of Slovak banking system. While the characteristics of Slovak banking sector have been subject to several research studies, being it analysis of its effectiveness or overall economic performance, and are frequently discussed in relevant policy-related studies (annual reports by the National Bank of Slovakia), the question of regional aspects and network structure of banking system in Slovakia has been so far understudied.

Our study therefore fits into the relevant literature in the following ways. Firstly, we look at the effect of local branch localization on output productivity of city regions in Slovakia, hence complementing the studies in regional sciences area (e.g. [3]). Secondly, we investigate potential effect of distance from regional centre to local bank branch that is often hypothesised to introduce some type of local spatial discrimination. Since the seat of regional firm bank centres is often located in major regional city centre we indirectly also introduce measure of the potential effects of functional distance into our analysis. Thirdly, we not only investigate pure effect of bank presence in local economies but also account for qualitative characteristics of individual banks that consequently shape the local bank environment. By taking this approach, we aim to address the role of quality (rather than quantity) of local bank environment in potential regional economic development.

\section{Literature review}

\subsection{City regions and economic productivity}

In recent years, the perception and position of cities in the economic system of countries has once again received much attention. The main reason for the increased interest in urban issues around the world lies mainly in the growing urbanization, which has been in intensive form for decades and according to the [4], in the upcoming years this trend will continue. As the population of cities grows, further development of entrepreneurial activities and an increase of the total output of cities can be expected.

The standard indicator used to explain the economic growth of countries and regions, gross domestic product (GDP), is also employed to investigate economic growth of cities, but to a less extent due to limited data availability. Rather, researchers use it to assess larger territorial units, such as urbanized regions. For example, [5] analyse GDP of metropolitan regions in the US. [6] compares GDP of the largest cities across the world, or Parkinson et al. (2015) investigate GDP trend between major and smaller urbanized regions in Europe. Employment development is also a common indicator for measuring the economic growth of cities [7]. Another indicator used to capture the economic superiority of cities is factor productivity [8]. Using the labor productivity as an indicator of growth of cities [9] the study concludes that cities are more productive than non-urbanized (rural) areas, mainly because of the concentration of human capital in cities. 
In the context of urban economic growth, the size of the city plays a specific role. The main advantage of large cities is that they bring together a large number of actors in their territory, who benefit from localization in close proximity. That allows creating agglomeration benefits, which in turn enable cities to achieve high levels of production and continue to grow. Different city sizes and their roles in the economic system of countries is currently a much-debated topic. An article by [10] points out that at the turn of the millennium, growth and population concentration as well as economic growth in Europe's largest cities, slowed. While in the last decades of the last century the population and total production have increased, especially in the largest European cities, but according to authors this has not been the case since the late 1990s and at the beginning of the new millennium. [11] gave a discussion that secondary towns can and do contribute to the economic performance of national economies across European countries. Based on an analysis of the economic performance of 150 cities from 31 European countries, the authors found that national governments should invest more in secondary and smaller cities, because those countries that did so before the economic recession, subsequently coped better with the economic crisis than countries that focused only on supporting largest cities.

Local presence of bank branches and its effect on SME's access to finance is investigated in [3] who conclude that greater functional distance between bank headquarters and branches exacerbates the credit constraints faced by local SMEs. From [12] findings it is clear that banking activities have significant positive impact on the per capita local output growth of regions. Especially on those that are distant from the financial centre. However, when bank loans are adjusted to the size of the local economy, the relation between banking activities and the output is found to be negative. Furthermore, [1] studies whether distance shapes credit allocation by estimating the impact of bank branches closings in US regions on local access to credit. She concludes that closings of bank branches lead to a persistent decline in local small business lending. Last but not least, the effects of branch expansion and geographical strategies on the efficiency of banks in Italy were examined by [13]. According to authors, except for banks with a more diversified product offering expansion has a negative impact on efficiency and is exacerbated by increased distance between the headquarters and branches. Efficient local banks and larger credit availability boost local economy, while a bank structural change by a branch expansion generates a negative effect in terms of local economic development.

\subsection{Bank branch network and spatial aspect}

Effect of local bank branch presence is highly dependable on not only local conditions but also on structure of local banking market itself. [14] describes spatial dimension of bank branch networks by the following three distinct categories: (i) operational distance, i.e. distance between customer and bank branch, (ii) functional distance, i.e. distance between local bank branch and bank headquarters, (iii) interbank distance, i.e. distance between local bank branch and nearest competitors.

Following the authoritative treatment (i.e. geography matters) in [15], [16] show that financial development tends to be spatially correlated. Further exploratory investigation of spatial correlation in financial system by use of standard descriptive tools (Moran's spatial correlation) is performed in [17].

Effectiveness of bank branch operations is likely to depend on distance among them and branch network size [18]. Thus, spatial discrimination might materialize in observed differences in local credit provisioning policies affecting volume and price of available financial funds. Local financial markets might also operate as separate entities, as recently showed in [19], who by use of credit-deposit gap among regions find strong home bias and no fund-transferring among bank branches located in different regions. 
Most of the studies in this area of research are country-specific focusing on major advanced economies (Italy, US, UK) with China being the exception due to its recent popularity. Additionally, spatial dimension in local banking is usually investigated in space but not in time resulting in publication on cross-sectional studies (e.g. [2]) but lacking the view on dynamics of local markets. Only recently, two databases were compiled who take a more cross-country approach (OeNB database for CEE region and EBRD database for 22 countries).

\section{Model and data}

\subsection{Cobb-Douglas production function and regression specification}

In order to model effect of bank branch localization on regional output we use standard Cobb-Douglas production function. In what follows we adapt approach in [20]. The production function in its general form with elasticity of substitution equalling unity is given by the following:

$$
\mathrm{Q}_{\mathrm{it}}=\mathrm{AK}_{\mathrm{it}}^{\beta_{1}} \mathrm{~L}_{\mathrm{it}}^{\beta_{2}}
$$

where $Q$ it represents the total production, $A$ the total factor productivity, $K$ it level of capital stock, $L \_$it labor stock, $\beta \_1$ total output elasticity of capital and $\beta \_2$ total output elasticity of labor in region $i$ at time $t$.

Dividing the (1) by labor stock $L_{-}$it, taking logarithms and introducing the vector of other control variables $X^{\wedge} j_{-}$it the (1) can be rewritten in the following form:

$$
\ln \left(Q_{i t} / L_{i t}\right)=\ln (\overline{\mathrm{A}})+\beta_{1} \ln \left(K_{i t} / L_{i t}\right)+\left(\beta_{1}+\beta_{2}-1\right) \ln \left(L_{i t}\right)+\beta_{j} X_{i t}^{j}
$$

The theoretical relationship in (2) is estimated by the fixed effect model with both, region-specific $\mu \_i$ and time-specific $\tau_{-} t$ effects. Vector $X^{\wedge} j \_i t$ consist of variables capturing selected regional characteristics (quality of labor stock, entrepreneurial activity) and characteristics of local bank markets described below. The empirical model thus takes the following form:

$\ln \left(Q_{i t} / L_{i t}\right)=\ln (\mathrm{A})+\beta_{1} \ln \left(K_{i t} / L_{i t}\right)+\left(\beta_{1}+\beta_{2}-1\right) \ln \left(L_{i t}\right)+\beta_{j} X_{i t}^{j}+\mu_{i}+\theta_{t} \tau_{t}+\varepsilon_{i t}(3)$

\subsection{IV-2SLS estimation method}

The effect of financial development on overall economic development has been widely recognized (e.g. [21]). More specifically, access to finance plays a crucial role as financial system imperfections substantially limit growth potential especially for the most vulnerable players, such as households and small and medium enterprises.

However, recent empirical evidence shows that this relationship might be bidirectional [22] and financial access itself might be driven by economic considerations of relevant players (i.e. bank management) who might prefer to locate their offices in regions with better growth potential. This introduces potential endogeneity bias into the (3) due to the reverse causality when variable measuring number of bank branches (or other bank characteristics) might be correlated with error term. In order to address this possibility, we estimate the specification in (3) by instrumental variables (IV henceforth) 2SLS with time and year fixed effects. Results from the standard fixed effect model are available upon request.

When employing the two-stage regression with IVs, the choice of instrumental variable represents one of the key steps in this procedure. By assumption, the variable serving as the IV needs to be correlated with instrumented variable but her expected value conditional on error term should be zero. In the context of our study, the instrumental 
variable needs to be correlated with number of bank branches in the region but should not be affected by level of economic output of a region.

We hypothesise that number of bank branches will be affected by two factors: (i) representativeness of bank brands in a region, and (ii) a situation in neighbouring regions. More concretely, we firstly measure how many bank groups out of total possible (10) are present in a region and denote this indicator as a bank group diversification indicator. In the second step, we construct a space matrix measuring inverse of geographical distance between centroids of our city regions. By multiplication of bank group diversification indicator with space matrix we obtain information about connectedness of given city regions and their importance for their neighbours in terms of diversification possibilities. Finally we calculate the out-strength degree indicator (for definition see [23]) for each regions which provides information about the overall importance of a given region in the Slovak banking network in terms of variety of bank group brands present and available to potential customers. The higher the indicator, the higher the overall offer and this should be positively correlated with higher number of local branches. We test for hypothesised onedirectional causality between IV and dependent variable by simple fixed effect model. Results confirm that while there is no statistically significant impact of our instrument on regional output, there is a strong connection between instrument and number of local branches. The strength of the instrument is further tested by in the IV-2SLS regression by standard weak identification test.

\subsection{Dataset description}

For our analysis we use several datasets from different sources. Data are collected for three years $(2005,2010$ and 2016). As our objects of observation, we use definition of urban regions by [24]. The definition of Slovak urban region was based on the harmonized definition of urban areas, which was developed by the European Commission and the OECD ([25]).

From the survey for enterprises with 20 and more employees (provided by the Statistical Office of Slovak Republic) we obtain data that allow us to calculate the total output of every city region (sum of added values), stock of capital, number of employees and number of firms within every region.

The information regarding the number of bank branches operating in specific regions is taken from the official database published by the National Bank of Slovakia and data are transformed from quarterly to annual frequency by averaging over respective year. The information regarding the localization of units of bank branches that do not operate as foreign subsidiaries in Slovakia are dropped from the database.

As the dataset spans over more than a decade, few banks in our sample went through mergers or acquisitions. In the acquisition case the bank is usually taken over by a new owner, but from the perspective of our study no new unit is created, hence this event does not need to be specifically addressed. Contrary to that, in the case of merger the observations of the subordinated bank are added to the dominant bank and bank characteristics are then calculated from the new merged unit. Altogether we identify nine individual bank group operating in Slovakia during the period analysed.

Relevant characteristics of banking group include ROA as a measure of bank effectiveness, loans-to-assets ratio and fees-to-interest income ratio as a measure of orientation towards traditional core business bank activities, and unit employee costs as an approximation of quality of human capital. These individual bank group characteristics are accompanied by a measure of overall local market competition level calculated by HHI index of concentration based on number of bank branches located in a region per bank group. In order to measure characteristics of a local bank market we construct weighted 
averages of respective indicators by multiplying number of bank branches belonging to a particular banking group by the value of indicator associated with this banking group.

Table 1. Data description.

\begin{tabular}{|l|l|l|}
\hline \multicolumn{1}{|c|}{ Variable name } & \multicolumn{1}{|c|}{ Description } & \multicolumn{1}{c|}{ Source } \\
\hline $\begin{array}{l}\text { Output per employee } \\
\text { Q/L) }\end{array}$ & $\begin{array}{l}\text { Regional output per total number } \\
\text { of employees }\end{array}$ & $\begin{array}{l}\text { Statistical Office of } \\
\text { the Slovak Republic }\end{array}$ \\
\hline $\begin{array}{l}\text { Bank branches per } \\
\text { capita (BPC) }\end{array}$ & $\begin{array}{l}\text { Total number of bank branches per } \\
\text { total population in a region }\end{array}$ & $\begin{array}{l}\text { Statistical Office of } \\
\text { the Slovak Republic }\end{array}$ \\
\hline Capital intensity (K/L) & $\begin{array}{l}\text { Total capital over number of } \\
\text { employees }\end{array}$ & $\begin{array}{l}\text { Statistical Office of } \\
\text { the Slovak Republic }\end{array}$ \\
\hline $\begin{array}{l}\text { Number of employees } \\
\text { (L) }\end{array}$ & Total number of employees & $\begin{array}{l}\text { Statistical Office of } \\
\text { the Slovak Republic }\end{array}$ \\
\hline Quality of labour (H) & $\begin{array}{l}\text { Tertiary educated people over per } \\
\text { total population in a region }\end{array}$ & $\begin{array}{l}\text { Statistical Office of } \\
\text { the Slovak Republic }\end{array}$ \\
\hline $\begin{array}{l}\text { Regional capital city } \\
\text { (reg_capital) }\end{array}$ & $\begin{array}{l}\text { Regional capital at NUTS3 level, } \\
\text { dummy variable }\end{array}$ & Own construction \\
\hline $\begin{array}{l}\text { Total firms per capita } \\
\text { (FPC) }\end{array}$ & $\begin{array}{l}\text { Total number of firms per total } \\
\text { population in a region }\end{array}$ & $\begin{array}{l}\text { Statistical Office of } \\
\text { the Slovak Republic }\end{array}$ \\
\hline $\begin{array}{l}\text { Return on assets } \\
\text { (ROA) }\end{array}$ & $\begin{array}{l}\text { Net income before taxes over total } \\
\text { assets, weighted average for region }\end{array}$ & $\begin{array}{l}\text { Own calculation, } \\
\text { Annual reports }\end{array}$ \\
\hline $\begin{array}{l}\text { Loans to total assets } \\
\text { (LTA) }\end{array}$ & $\begin{array}{l}\text { Loans to customers over total } \\
\text { assets, weighted average for region }\end{array}$ & $\begin{array}{l}\text { Own calculation, } \\
\text { Annual reports }\end{array}$ \\
\hline $\begin{array}{l}\text { Fees to interest income } \\
\text { (FTI) }\end{array}$ & $\begin{array}{l}\text { Gross fees and commissions } \\
\text { income over gross interest income, } \\
\text { weighted average for region }\end{array}$ & $\begin{array}{l}\text { Own calculation, } \\
\text { Annual reports }\end{array}$ \\
\hline $\begin{array}{l}\text { Unit employee costs } \\
\text { (UEC) }\end{array}$ & $\begin{array}{l}\text { Total personal costs over number } \\
\text { of employees, weighted average } \\
\text { for region }\end{array}$ & $\begin{array}{l}\text { Own calculation, } \\
\text { Annual reports }\end{array}$ \\
\hline
\end{tabular}

In general, the bank network of individual bank groups in Slovakia is designed as a two-tier structure with local bank branches serving households and small and medium terms spread all over the Slovak regions and big corporate centres servicing important bigsize business located in core regional cities. In order to reflect this particular network structure we introduce an interaction term between number of branches per capita and dummy variable for core regional capital cities at NUTS 3 level.

As typical for the standard Cobb-Douglas production function, we control for capital intensity, quantity and quality of human capital. The access to finance is approximated by total number of bank branches per citizen in a region irrespective of bank group. More detailed description of variables and sources of data is given in the Table 1. 


\section{Results and discussion}

In the Table 2 we provide results from the benchmark regression as in (3). The relevant local bank market characteristics are introduced in a step-by-step fashion due to their potential collinearity.

As apparent, the measure of local bank market saturation (i.e. access to finance) bank branches per capita indicator is not associated with increase in regional output. Contrary to the expectations, the negative coefficient, even though not statistically significant, might potentially lead to a conclusion that higher number of bank branches is associated with decrease in regional output. This, at first sight, surprising result might, however, have a plausible explanation once thinking in terms of optimal saturation of a market. If the local markets already operate on optimum, hence current access to finance is sufficient to cover all past and future needs of economic agents in the region, then opening a new bank branch might result in no increase in total local production. On top of that, while the effect on local employment might be positive, withdrawal of skilled labour stock from pool of potential entrepreneurs and firm employees might lead to even decrease in total productivity. From this perspective, overall structure of Slovak banking network may truly show signs of an optimal allocation and recent trend in closing down of selected local bank branches might be perceived as a positive step in direction of cutting off of unnecessary costs.

Table 2. Regression results.

\begin{tabular}{|c|c|c|c|c|c|c|}
\hline $\begin{array}{l}\text { Dep. variable }= \\
\log (\mathrm{Q} / \mathrm{L})\end{array}$ & (1) & (2) & (3) & (4) & (5) & (6) \\
\hline $\log (\mathrm{BPC})$ & $\begin{array}{l}-0.504 \\
(0.21)\end{array}$ & $\begin{array}{l}-0.431 \\
(0.24)\end{array}$ & $\begin{array}{l}-0.442 \\
(0.22)\end{array}$ & $\begin{array}{l}-0.442 \\
(0.25)\end{array}$ & $\begin{array}{l}-0.599 \\
(0.19)\end{array}$ & $\begin{array}{l}-0.284 \\
(0.44)\end{array}$ \\
\hline $\log (\mathrm{K} / \mathrm{L})$ & $\begin{array}{l}0.374 * * * \\
(0.00)\end{array}$ & $\begin{array}{l}0.395^{* * * *} \\
(0.00)\end{array}$ & $\begin{array}{l}0.361 * * * \\
(0.00)\end{array}$ & $\begin{array}{l}0.388 * * * \\
(0.00)\end{array}$ & $\begin{array}{l}0.384 * * * \\
(0.00)\end{array}$ & $\begin{array}{l}0.391 * * * \\
(0.00)\end{array}$ \\
\hline $\log (\mathrm{L})$ & $\begin{array}{l}0.352 * * * \\
(0.00)\end{array}$ & $\begin{array}{l}0.359 * * * \\
(0.00)\end{array}$ & $\begin{array}{l}0.319 * * * \\
(0.01)\end{array}$ & $\begin{array}{l}0.346^{* * * *} \\
(0.00)\end{array}$ & $\begin{array}{l}0.364 * * * \\
(0.00)\end{array}$ & $\begin{array}{l}0.311 * * * \\
-0.01\end{array}$ \\
\hline $\log (\mathrm{H})$ & $\begin{array}{l}0.513 \\
(0.19)\end{array}$ & $\begin{array}{l}0.668 \\
(0.10)\end{array}$ & $\begin{array}{l}0.321 \\
(0.38)\end{array}$ & $\begin{array}{l}0.525 \\
(0.17)\end{array}$ & $\begin{array}{l}0.626 \\
(0.15)\end{array}$ & $\begin{array}{l}0.583 \\
(0.12)\end{array}$ \\
\hline $\log (\mathrm{BPC}) *$ reg_capital & $\begin{array}{l}0.790 * \\
(0.08)\end{array}$ & $\begin{array}{l}0.647 \\
(0.11)\end{array}$ & $\begin{array}{l}0.799 * \\
(0.07)\end{array}$ & $\begin{array}{l}0.583 \\
(0.19)\end{array}$ & $\begin{array}{l}0.841^{*} \\
(0.08)\end{array}$ & $\begin{array}{l}0.528 \\
(0.20)\end{array}$ \\
\hline $\log (\mathrm{FPC})$ & $\begin{array}{l}-0.207 \\
(0.46)\end{array}$ & $\begin{array}{l}-0.231 \\
(0.39)\end{array}$ & $\begin{array}{l}-0.24 \\
(0.37)\end{array}$ & $\begin{array}{l}-0.243 \\
(0.37)\end{array}$ & $\begin{array}{l}-0.192 \\
(0.50)\end{array}$ & $\begin{array}{l}-0.195 \\
(0.46)\end{array}$ \\
\hline ROA weighted mean & & $\begin{array}{l}0.380 * \\
(0.07)\end{array}$ & & & & \\
\hline LTA weighted mean & & & $\begin{array}{l}-0.027 * * \\
(0.05)\end{array}$ & & & \\
\hline FTI weighted mean & & & & $\begin{array}{l}2.635^{*} \\
(0.05)\end{array}$ & & \\
\hline UEC weighted mean & & & & & $\begin{array}{l}0.030 \\
(0.34)\end{array}$ & \\
\hline HHI & & & & & & $\begin{array}{l}0.667 * \\
(0.08) \\
\end{array}$ \\
\hline $\mathrm{F}$ & 55.34 & 52.81 & 53.38 & 52.45 & 46.70 & 55.52 \\
\hline $\mathrm{N}$ & 185 & 185 & 185 & 185 & 185 & 185 \\
\hline R2 (within) & 0.79 & 0.8 & 0.8 & 0.8 & 0.78 & 0.81 \\
\hline
\end{tabular}


Cragg-Donald Wald F-

\begin{tabular}{lllllll} 
stats & 12.268 & 14.354 & 14.554 & 12.196 & 9.912 & 12.993 \\
\hline Note: & $*$ denotes significance at & 10-percent, & ** denotes significance at & 5 -percent, & $* * *$ denotes
\end{tabular} significance at 1-percent. Stock-Yogo weak ID test critical values: (i) $10 \%$ maximal IV size $=16.38$, (ii) $15 \%$ maximal IV size $=8.96$, (iii) $20 \%$ maximal IV size $=6.66$, (iv) $25 \%$ maximal $\mathrm{IV}$ size $=5.53$.

As hypothesised, regional centres serving predominantly to the major businesses located in regional capitals are more likely to provide an additional rise in productivity, as showed by the statistically significant and positive coefficient associated with interaction term. However, this finding is not robust across different specifications and disappears once controlling for particular characteristics of local banking market.

Local bank markets populated by more efficient banks (ROA) oriented on provision of other than traditional (i.e. core) banking activities (FTI) leads to higher regional productivity. The negative coefficient associated with LTA indicator also corroborates our previous findings showing that further orientation on simple credit provisioning on expenses of other, more sophisticated, activities might even harm the future productivity potential of regions. One potential explanation shedding some light on our results might be related to recent popularity of mortgage-based banking business model. While dramatic increase in provision of mortgages to households in recent years might be viewed as a positive trend by general public, potential crowding-out effect of private investments of local firms might harm local firms who stand exactly at the margins, being it small and medium enterprises or young start-up firms. On top of that, in the presence of international trade and competition increase in credit provisioning to households in terms of consumer loans provided by local bank branches might ultimately benefit other regions (states) rather than those where consumers live and spend their money.

Interestingly, higher productivity might be observed in regions where there is a less competing environment among individual bank groups. One plausible explanation might be associated with traditional relationship-based banking activity that favours banks that know their clients, thus are able to better accommodate their needs. In this case the arrival of a new competitor might destroy these linkages if the competition indeed leads to decreasing costs of capital but on the expenses of quality of underlying services. Excessive credit provisioning might result in funding of projects that are potentially meaningless.

The positive and statistically significant results for capital intensity and quantity of labour capital support standard economic theory. Weak identification test for instruments shows that in general our instruments should not suffer extensively from the weak identification issue.

As part of the robustness check we estimate regression (3) without Bratislava and Kosice city region as these two might behave in a completely different way due to their particular roles. Results, available upon request, again confirm significant results for LTA and FTI indicators. Interestingly, the added value for regional capital city (i.e. interaction term) was not confirmed once excluding two major centres in Slovakia. This might indicate that even if centres for big-size businesses are located in different regions than the ultimate seat of a firm, the benefits of access to finance are likely to be attributed to that target region, as logic dictates.

\section{Conclusions}

We investigate role of bank branches in Slovakia in regional output productivity by the IV-2SLS approach. Our dataset include more than 60 city regions for three years distanced by 5 - year gap in order to capture long-term dynamics. We introduce five measures of local bank market characteristics that reflect effectiveness, competition and character of banks operating in these local markets. Instrument used to model bank branch 
availability is calculated as the out-strength degree measure based on bank branch network created as a combination of geographical distance and representation of individual bank brands in a particular region. Our findings suggest that while there is no observable effect of bank branch presence on regional productivity, local bank market characteristics matter. In particular, more effective banks less oriented on traditional banking activities might help to boost the local productivity of firms. We hypothesize that already high level of saturation in local banking markets might results in negligible or even adverse effects on local productivity found in our data.

Siranova acknowledges support from the Czech Science Foundation, grant number GACR 1919485S.

\section{References}

1. Q. H. Nguyen, Are Credit Markets Still Local? Evidence from Bank Branch Closings. American Economic Journal: Applied Economics 11, 1-32 (2019)

2. A. Tranfaglia, Shrinking Networks: A Spatial Analysis of Bank Branch Closures. Federal Reserve Bank of Philadelphia Research Department Working Papers WP, 18-12 (2018)

3. T. Zhao, D. Jones-Evans, SMEs, banks and the spatial differentiation of access to finance, Journal of Economic Geography 17, 791-824 (2017)

4. United Nations. World urbanization prospects - 2014 Revision (2014)

5. R. Florida, Ch. Mellander, K. Stolarick, Human capital in cities and suburbs. Annals of Regional Science 57, 91-123 (2016)

6. E. Glaeser, Triumph of the City: How Urban Spaces Make Us Human. (Penguin Press, London, 2011)

7. C. J. Simon, C. Nardinelli, Human Capital and the rise of American cities, 19001990, Regional Science and Urban Economics 32, 59-96 (2002)

8. A. Ciccone, R. Hall, Productivity and the density of economic activity. American Economic Review 86, 54-70 (1996)

9. J. Rauch. Productivity Gains from Geographic Concentration of Human Capital: Evidence from the Cities, 34, 380-400 (1993)

10. L. Dijkstra, E. Garcilazo, P. McCann, The Economic Performance of European Cities and City Regions: Myths and Realities. European Planning Studies 21, 334354 (2013)

11. M. Parkinson, R. Meegan, J. Karecha, City size and economic performance: is bigger better, small more beautiful of middling marvellous? European Planning Studies 23, 1054-1068 (2015)

12. S. Özyildirim, Z. Önder, Banking Activities and Local Output Growth: Does Distance from Centre Matter? Regional Studies 42, 229-244 (2008)

13. Ch. Bernini, P. Brighi, Bank branches expansion, efficiency and local economic growth. Regional Studies 52, 1332-1345 (2017)

14. L. Papi, E. Sarno, A. Zazzaro, The geographical network of bank organizations: Issues and evidence for Italy. MOFiR Working Paper no. 105 (2015)

15. R. De Haas, N. Van Horen, Running for the Exit: International Banks and Crisis Transmission. Review of Financial Studies 26, 244-285 (2013) 
16. X. Yu, M. Li., S. Huang, Financial Functions and Financial Development in China: A Spatial Effect Analysis. Emerging Markets Finance and Trade 53, 20522062 (2017)

17. M. F. Crocco, Santos, P. V. Amaral, The Spatial Structure of Financial Development in Brazil. Spatial Economic Analysis 5, 181-203 (2010)

18. B. Hirtle, The Impact of Network Size on Bank Branch Performance. Journal of Banking and Finance 31, 3782-3805 (2007)

19. Aguirregabiria, V. Clark, H. Wang, The Geographic Flow of Bank Funding and Access to Credit: Branch Networks, Local Synergies and Competition. CEPR Discussion papers no. 13741, (2019)

20. V. Nemethova, M. Sipikal, M. Siranova, Public support for firms in lagging regions - Evaluation of Innovation Subsidy in Slovakia. Science and Public Policy 46, 173-183 (2019)

21. I. Hasan, R. Horvath, J. Mares, What type of finance matters for growth? Bayesian model averaging evidence. World Bank Economic Review 32, 383-409 (2018)

22. R. Horvath, E. Horvatova, M. Siranova, Financial development, rule of law and wealth inequality: Bayesian model averaging evidence. BOFIT Discussion Papers 12 (2017)

23. M. Siranova, European banking network in light of the single supervisory mechanism from the network analysis perspective. Financial assets and investing 6, 35-57 (2015)

24. O. Rafaj, S. Rehak. 6th Central European Conference in Regional Science: Engines of Urban and Regional Development (2017)

25. L. Dijkstra, H. Poelman, A harmonized definition of cities and rural areas: the new degree of urbanization. A series of short papers on regional research and indicators produced by the Directorate-General for Regional and Urban Policy. WP 01, (2014) 